\title{
Non-kin Cooperation in Ants
}

\author{
Andrew V. Suarez ${ }^{1,2+}$ and Michael A. D. Goodisman ${ }^{3 * t}$ \\ ${ }^{1}$ Department of Evolution, Ecology and Behavior, University of Illinois, Champaign, IL, United States, ${ }^{2}$ Department \\ of Entomology, University of Illinois, Champaign, IL, United States, ${ }^{3}$ School of Biological Sciences, Georgia Institute \\ of Technology, Atlanta, GA, United States
}

Eusociality represents an extreme form of social behavior characterized by a reproductive division of labor. Eusociality necessarily evolved through kin selection, which requires interactions among related individuals. However, many eusocial taxa also show cooperation between non-kin groups, challenging the idea that cooperative actions should only occur among relatives. This review explores the causes and consequences of non-kin cooperation in ants. Ants display a diversity of behaviors that lead to non-kin cooperation within and between species. These interactions occur among both reproductive and non-reproductive individuals. The proximate and ultimate mechanisms leading to non-kin cooperative interactions differ substantially depending on the biotic and abiotic environment. We end this review with directions for future research and suggest that the investigation of non-kin cooperative actions provides

OPEN ACCESS

Edited by:

Floria M. K. Uy,

University of Rochester, United States

Reviewed by:

Clint Penick,

Kennesaw State University,

United States

Sheng-Feng Shen,

Academia Sinica, Taiwan

*Correspondence:

Michael A. D. Goodisman

michael.goodisman@

biology.gatech.edu

tThese authors have contributed

equally to this work

Specialty section:

This article was submitted to

Social Evolution,

a section of the journal

Frontiers in Ecology and Evolution

Received: 05 July 2021 Accepted: 13 September 2021 Published: 07 October 2021

Citation:

Suarez AV and Goodisman MAD

(2021) Non-kin Cooperation in Ants.

Front. Ecol. Evol. 9:736757.

doi: 10.3389/fevo.2021.736757 insight into processes leading to social evolution.

Keywords: conflict, cooperation, haplometrosis, parabiosis, mutualism, polygyny, pleometrosis, foundress associations

\section{INTRODUCTION}

Cooperation is a fundamental part of life and occurs among entities at all levels of biological organization (Maynard Smith and Szathmary, 1998). A general evolutionary definition of cooperation is a behavior which benefits another individual, and which has been selected for because of its positive effects on both participants (after West et al., 2007b). Thus, the focal social behaviors must have evolved at least partially because of the fitness benefits that they produce (West et al., 2007b). These fitness benefits can be either direct or indirect. Direct fitness benefits refer to gains in a focal individual's own reproductive success. Indirect fitness benefits result from increased reproductive success for relatives of the cooperating individual (Hamilton, 1964).

Cooperation within species of eusocial insects usually occurs between relatives. That is, the stereotypical lifestyle for a eusocial insect colony is that of a cooperative, family group (Hölldobler and Wilson, 1990; Ross and Matthews, 1991; Hughes et al., 2008). A "standard" eusocial hymenopteran colony is often headed by a single queen who produces the worker offspring that cooperate to build the nest, rear the young, forage, etc. The workers do not gain direct benefits for such actions, since they are (more or less) sterile. Instead, they receive indirect benefits by cooperating because they rear related offspring that will pass on their genes. This familial system of cooperation and reproductive altruism can evolve because the nestmates are related. If they were not, then such cooperative systems with reproductive altruists (e.g., sterile workers) could not evolve (Kay et al., 2020).

Surprisingly, eusocial insects sometimes engage in non-kin cooperative behaviors (Jackson, 2007; Helantera et al., 2009; Leniaud et al., 2009; Lehmann and Rousset, 2010; Moffett, 2012; Boomsma and d'Ettorre, 2013; Hakala et al., 2020; Ostwald et al., 2021). Such actions are unexpected because eusocial insects are the paradigm of kin cooperative actions. Nevertheless, 
cooperative behaviors among non-kin occur in several different contexts. Such interactions require careful examination and explanations, because they would seem to contradict traditional models of cooperation in these taxa.

The purpose of this review is to examine non-kin cooperative behaviors in ants. We define non-kin here as associations where relatedness is low (e.g., zero or near zero), and consequently there are little to no indirect benefits from helping relatives. We discuss cases were non-kin cooperation may occur within species. Such situations encompass most well-studied and well-known examples of intraspecific cooperation between non-relatives. In addition, we extend our review to include unusual instances of cooperation among non-kin that occur in species with unusual genetic systems. We also consider cases of interspecific behaviors as instances of non-kin cooperative actions. The causes and consequences of interspecific cooperation differ from those for intraspecific cooperation, thereby providing useful points of comparison. Finally, we provide suggestions for areas of future research in non-kin cooperation (West et al., 2021).

Our review specifically focuses on non-kin cooperation in ants. Ants are perhaps the most well-studied eusocial insects in terms of taxonomic breadth (Hölldobler and Wilson, 1990), and diverse examples of non-kin cooperative actions in ants have been identified (Figure 1). We discuss several of these examples to understand the proximate causes and ultimate consequences of these cooperative interactions. Overall, the study of non-kin cooperation in ants provides great insight into the evolution of social actions in animal societies.

\section{NON-KIN COOPERATION AMONG ANT QUEENS}

Most ant colonies are headed by a single reproductive queen (i.e., monogyne colonies), which is the likely ancestral condition for eusocial Hymenoptera generally (Hughes et al., 2008). However, multiple-queen (polygyne) colonies are common in ants and polygyny has evolved independently in nearly every ant subfamily (Hölldobler and Wilson, 1977; Keller, 1993). However, the exact number of times polygyny has evolved in ants, or the number of species that are polygyne, has not been quantified to our knowledge. Polygyny can arise through a variety of mechanisms including the recruitment of sisters from within the nest, the adoption of unrelated queens from other nests, and from newly mated queens cooperating to start new colonies (Hölldobler and Wilson, 1977; Figure 2). In this section, we discuss the ecology and evolution of polygyny, particularly as it relates to associations of non-kin queens. Such non-kin associations actually represent a fundamentally important part of the lifecycle of many ants.

\section{Primary Polygyny}

In many ant species, unrelated queens initiate colonies in groups, a process known as pleometrosis (Hölldobler and Wilson, 1977). These associations among reproductives are taxonomically widespread with examples in all four of the largest ant subfamilies (Ponerinae, Myrmicinae, Dolichoderinae, and Formicinae) (Bernasconi and Strassmann, 1999). The proximate mechanisms leading to queen aggregations are not well known and may be diverse. For example, queens may be attracted to the same microhabitats thereby ending up in the same location to establish a new nest (Tschinkel and Howard, 1983). Queens may also form pleometrotic assemblages by searching out other queens as suggested for some populations of the weaver ant, Oecophylla smaragdina (Peeters and Andersen, 1989; Crozier et al., 2010). It is even possible that queens locate each other using pheromones or other attractants (Aron and Deneubourg, 2020).

Natural selection will favor traits that lead to pleometrotic associations when the success of independent colony founding (haplometrosis) is very low (Shaffer et al., 2016; Haney and Fewell, 2018); independent colony founding rates are indeed estimated to be less than $1 \%$ in many ant species (Hölldobler and Wilson, 1990; Aron and Deneubourg, 2020). The formation of pleometrotic associations would therefore be driven by mutualism; kin selection (i.e., relatedness) would not necessarily play a role. Instead, an individual queen's direct fitness would be higher, on average, by joining a group than if she founded a colony independently. Similarly, groups should allow other queens to join as long as individual fitness increases with queen number and provided that group size does not reach a point of diminishing returns.

There are a number of benefits to pleometrotic associations (Bernasconi and Strassmann, 1999; Ostwald et al., 2021; Teggers et al., 2021), notably the ability to produce workers more quickly than through haplometrosis. Many species that form pleometrotic associations are highly territorial, and workers from established colonies may destroy or raid incipient colonies in their immediate vicinity. Quickly producing a large worker force will therefore increase forging, protect the colony, and increase the success of the focal colony's own raids. In addition, cooperating queens may display division of labor if they vary in their tendency to perform specific behaviors such as excavation (Helms Cahan and Fewell, 2004); by performing tasks such as digging, taking care of brood, and foraging in parallel, overall efficiency is increased during the critical stage of colony founding.

In some cases, pleometrotic associations may lead to permanently polygyne colonies (Figure 2). That is, the initial associations of unrelated queens persist through colony ontogeny. The proximate mechanisms leading to such associations have been investigated in some ant taxa (Clark and Fewell, 2014; Helmkampf et al., 2016; Overson et al., 2016; Shaffer et al., 2016; Eriksson et al., 2019; Masoni et al., 2019; Aron and Deneubourg, 2020). Despite the initial benefits of primary polygyny, it is believed to be relatively rare for pleometrotic associations to result in permanent polygyny (Hölldobler and Wilson, 1990; Bernasconi and Strassmann, 1999; Eriksson et al., 2019). While queens exist peacefully at the onset of pleometrotic associations, colony members may no longer tolerate each other after workers emerge. Queens may fight directly leading to a single, surviving reproductive, or queens may compete indirectly during production of their first brood (Teggers et al., 2021). For example, Solenopsis invicta fire ant queens vary in weight loss during reproduction in pleometrotic associations. These differences are associated with success as heavy queens are more likely to survive fights (Bernasconi and Keller, 1996; 


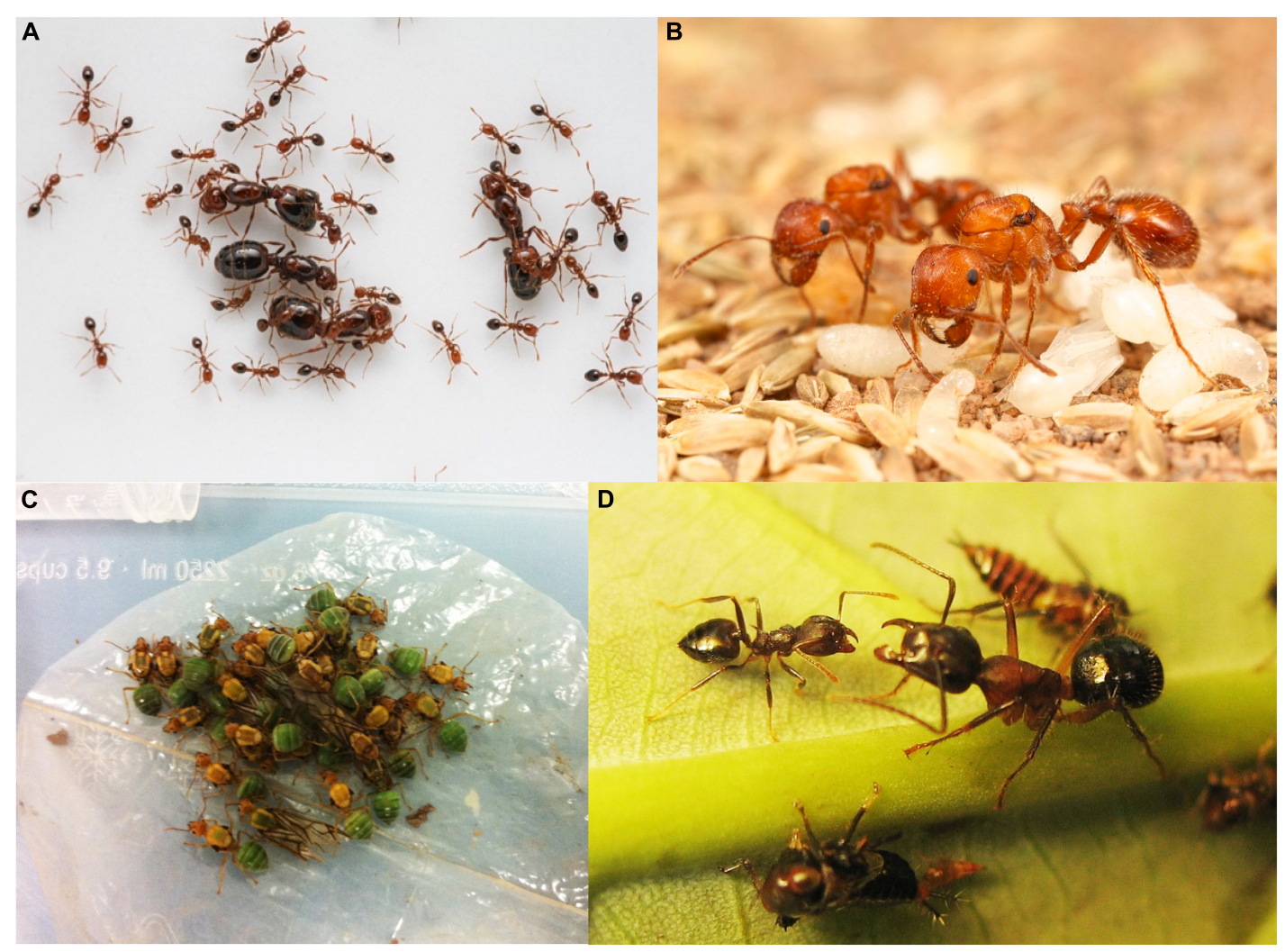

FIGURE 1 | Examples of ants that exhibit non-kin associations or variation in queen number along a continuum of relatedness. (A) Solenopsis invicta queens form polygyne colonies consisting of unrelated queens (photo credit: Haolin Zeng). (B) Pogonomyrmex californicus queens from a polygynous population (photo credit: Elizabeth Cash). (C) An association of over 20 Oecophylla smaragdina collected in Darwin, Australia from a rolled leaf where they had enclosed themselves (photo credit: Andrew Suarez). (D) Trophilaxis between Camponotus and Crematogaster workers in a parabiotic relationship in Malaysia (photo credit: Florian Menzel).

Bernasconi et al., 1997). Queens in pleometrotic associations of a variety of species will eat each other's eggs. This behavior not only increases their food intake, but also reduces worker production of rivals. Thus, queens may be preparing for fighting even while cooperating to start a new colony. Workers may also take part in the culling of queens, their eggs, or larvae. In S. invicta, workers do not treat their mother differently from other unrelated queens within the association, and may directly or indirectly participate in the destruction of their own mother. In Lasius and Messor, larvae eat eggs but there is no evidence that they can discriminate between related and unrelated eggs (Urbani, 1991). Thus, selection for direct kin helping in pleometrotic associations apparently does not occur. Given the lack of permanent polygyny in most pleometrotic species, a case could be made that these associations could be described as facultative or even competitive rather than cooperative.

\section{Secondary Polygyny}

Polygyny in ants typically occurs through secondary adoption of queens as the colony ages (Boomsma et al., 2014; Figure 2). Secondary polygyny, therefore, often leads to permanently polygyne nests. The proximate mechanisms leading to secondary polygyny likely differ from those that lead to primary polygyny in pleometrotic associations. However, we know surprisingly little about the proximate mechanisms leading to polygyne colonies and variation in polygyny within and among species. An exception is fire ants in the genus Solenopsis, where genetic variation at a large supergene plays a decisive role in the formation of polygyne nests (Krieger and Ross, 2005; Gotzek, 2007; Arsenault et al., 2020; Yan et al., 2020). In this case, workers behave differently toward queens of distinct supergene genotypes; this behavioral variation ultimately only leads to the acceptance of queens possessing heterozygous genotypes in polygyne colonies. The genes within the supergene influence the cues and behaviors used for this genetic discrimination (Fletcher and Blum, 1983) possibly through chemically mediated cues (Eliyahu et al., 2011; Trible and Ross, 2016) leading to an unusual green-beard phenomenon in this species (Keller and Ross, 1998).

The ultimate factors responsible for the evolution of polygyny have been more widely considered than the proximate factors (Keller, 1993). In particular, as with primary polygyny, selection will favor secondary polygyny when having multiple queens enhances colony success (Boulay et al., 2014) or if there is a low likelihood that queens can found colonies independently (Keller, 1991). For example, predation, nest site limitation, intraspecific competition, and nest raiding can select for queens to join established colonies. However, there could be selection against 


\section{Colony Founding Method}

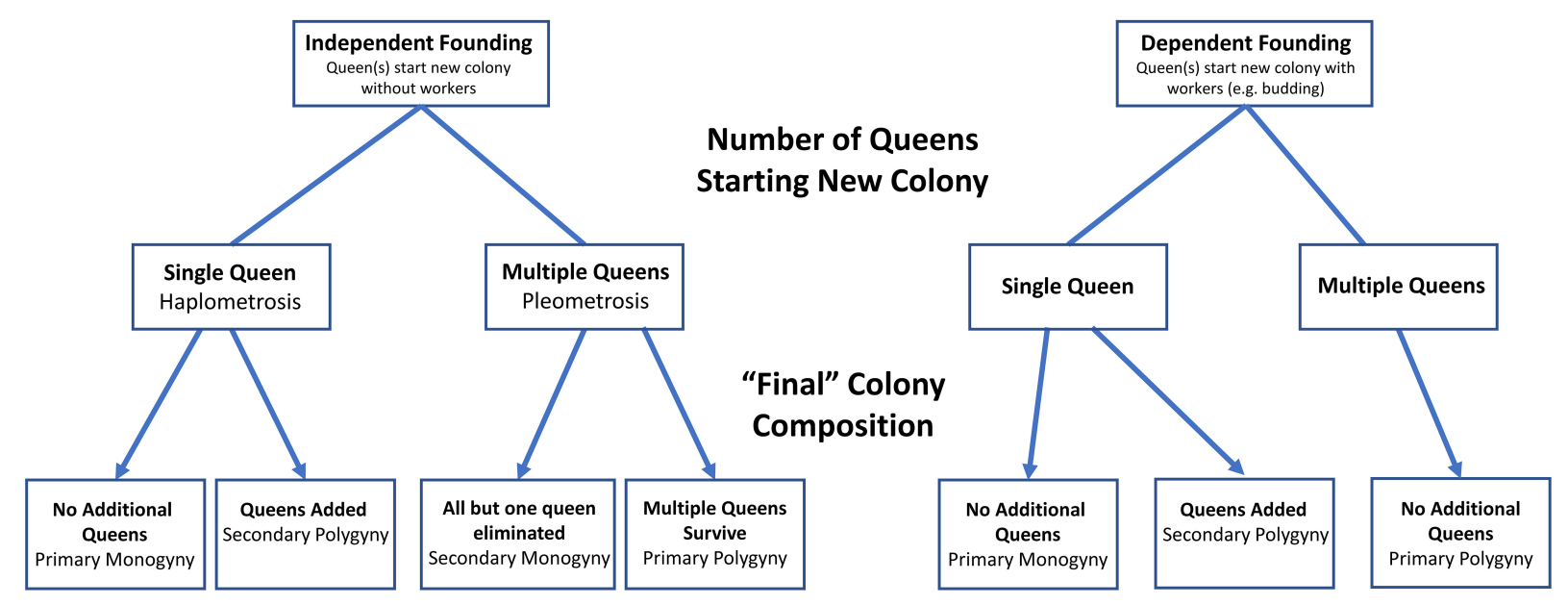

FIGURE 2 | Mechanisms leading to variation in colony-queen number in ants over time. Non-kin queen associations occur when alates from different nests come together to start new colonies (pleometrosis through independent colony founding) or when unrelated queens are adopted into existing colonies (secondary polygyny). Modified from Hölldobler and Wilson (1977).

queens and workers within existing colonies from allowing new queens to join. Polygyny can increase competition for resources and lead to conflict over reproduction among queens; an increase in queen number is often associated with a decrease in individual reproductive output. Moreover, polygyny decreases relatedness among nestmates, which reduces indirect benefits to workers and potentially increases intracolonial conflict. In many ants, polygyny is associated with "budding" reproduction where groups of queens establish new nests accompanied by a large retinue of workers (Cronin et al., 2013; Ellis and Robinson, 2014). Ants that found colonies by budding rather than independently also tend to invest less in the condition of each reproductive, which are subsequently no longer capable of founding colonies without the help of workers (Peeters and Ito, 2001).

It is likely the environment plays a strong role in determining where polygyny can occur and if queen condition restricts independent colony founding (Heinze and Tsuji, 1995; Purcell et al., 2015). Colonies should accept new queens if there is a strong likelihood that a colony will lose its own reproductive. This leads to a prediction that queen adoption, particularly from within the nest, should be more likely as a colony ages or as the current queen(s) condition worsens. Recruitment of new queens will also be selected for if the new queens introduce benefits to the colony such as those associated with increased genetic diversity generally. For example, workers in genetically diverse colonies may be more polymorphic, undertake a greater range of tasks, or better resist disease (Schwander et al., 2005; Smith et al., 2008; Schluns and Crozier, 2009; but see Fournier et al., 2008).

Under most circumstances, however, colonies should only accept relatives as new queens. Queens in most polygyne species are related, indicating that queen recruitment occurs from within the nest (Sundström et al., 2005). However, some ants have colonies that contain unrelated queens, indicating that non-nestmate recruitment occurs (Kummerli and Keller, 2007;
Seppa et al., 2012; Sorger et al., 2017; Brodetzki et al., 2020; Hakala et al., 2020). Such associations lead to non-kin cooperation among nestmates and, in these circumstances, would seem to be evolutionarily problematic.

Polygyny is overrepresented in invasive or tramp ant species (Heinze and Tsuji, 1995); in these cases, having large numbers of queens is linked to a variety to mechanisms that likely contribute to colony success (Holway et al., 2002; Boulay et al., 2014; Eyer and Vargo, 2021). For example, polygyny is associated with increased worker production, success of incipient colonies, and probability of transported propagules containing reproductives (Holway et al., 2002; Boulay et al., 2014; Bertelsmeier et al., 2017; Eyer and Vargo, 2021). Introduced species such as the Argentine ant, Linepithema humile, and little fire ant, Wasmannia auropunctata, can form expansive supercolonies (Giraud et al., 2002; Tsutsui and Suarez, 2003; Foucaud et al., 2009; Helantera et al., 2009). The size of their supercolonies is frequently associated with disturbance, even within native populations, suggesting that introduced ants may provide model systems for understanding widespread cooperation of individuals that are not direct relatives. Introduced $S$. invicta fire ants also form large polygyne colonies that recruit non-nestmate queens (Goodisman and Ross, 1998). In the US, the monogyne social form arrived first but has been replaced with polygyne form indicating some increased success of the polygyne social form under some circumstances.

\section{UNCONVENTIONAL GENETIC SYSTEMS AND NON-KIN COOPERATION IN ANTS}

An unusual form of non-kin cooperation has been found in some ant taxa that possess non-standard genetic and reproductive systems (Fournier et al., 2005; Ohkawara et al., 2006; 
Foucaud et al., 2007; Pearcy et al., 2011; Kronauer et al., 2012; Eyer et al., 2013; Rabeling and Kronauer, 2013; Okamoto et al., 2015; Lacy et al., 2019). For example, the longhorn crazy ant, Paratrechina longicornis, displays an unusual genetic system that leads to cooperative behaviors among "non-relatives" (Pearcy et al., 2011). Workers are produced through standard sexual reproduction between queens and males. However, queens are produced clonally and are genetically identical to their mothers. Strangely, males are also produced in a pseudoclonal fashion and are genetically identical to their fathers (i.e., androgenesis) (Goudie and Oldroyd, 2018). The mechanisms leading to androgenesis may be diverse (Goudie and Oldroyd, 2018). But research suggests that males may be derived from the elimination of the queen genome from diploid eggs or from fertilization of eggs lacking the queen genome altogether (Fournier et al., 2005; Foucaud et al., 2007, 2010; Schwander and Oldroyd, 2016).

The long-term consequence of ant species with odd genetic systems is that queens, males, and workers within colonies show substantial genetic differences. Workers are more closely related to workers from other colonies than they are to their parents or to their reproductive gyne and male "siblings" from their own colony (Figure 3). The relatedness dynamics are a bit awkward in these systems. Nevertheless, these do represent an instance of non-kin cooperation between the genetically differentiated worker, queen, and male castes within colonies.

An increasing number of non-standard genetic systems have been identified in ants in recent years (Eyer et al., 2019; Lacy et al., 2019). Therefore, it is possible that instances of this type of non-kin cooperation is even more common than expected. Non-standard reproductive systems may have evolved because they prevented certain types of inbreeding. Such systems also potentially lead to coadapted gene complexes within castes. However, the ultimate fate of species displaying these unusual genetic systems remains unclear.

\section{INTERSPECIFIC ASSOCIATIONS IN ANTS}

Research on non-kin associations in ants primarily focuses on intraspecific unions of queens. However, remarkably, cooperative associations between ants of different species also occur. For example, associative behaviors such as trail sharing (Wilson, 1965; Davidson, 1988) and nest sharing (i.e., parabiosis) (Davidson, 1988; Orivel et al., 1997; Errard et al., 2003; Sanhudo et al., 2008) can take place between species.

The evolutionary factors that lead to interspecific associations and cooperation between worker ants may be broadly similar to those that lead to non-kin interactions within species (Barker et al., 2017). That is, kin selection cannot be involved because the interactors are not related (West et al., 2011). Instead, both cooperating species must gain some direct benefits so the cooperative action is mutually beneficial (West et al., 2007a). Under this framework a variety of cooperative associations are possible.

Ants engaged in parabiotic associations cooperate in a variety of ways including shared nest defense, trophallaxis, and

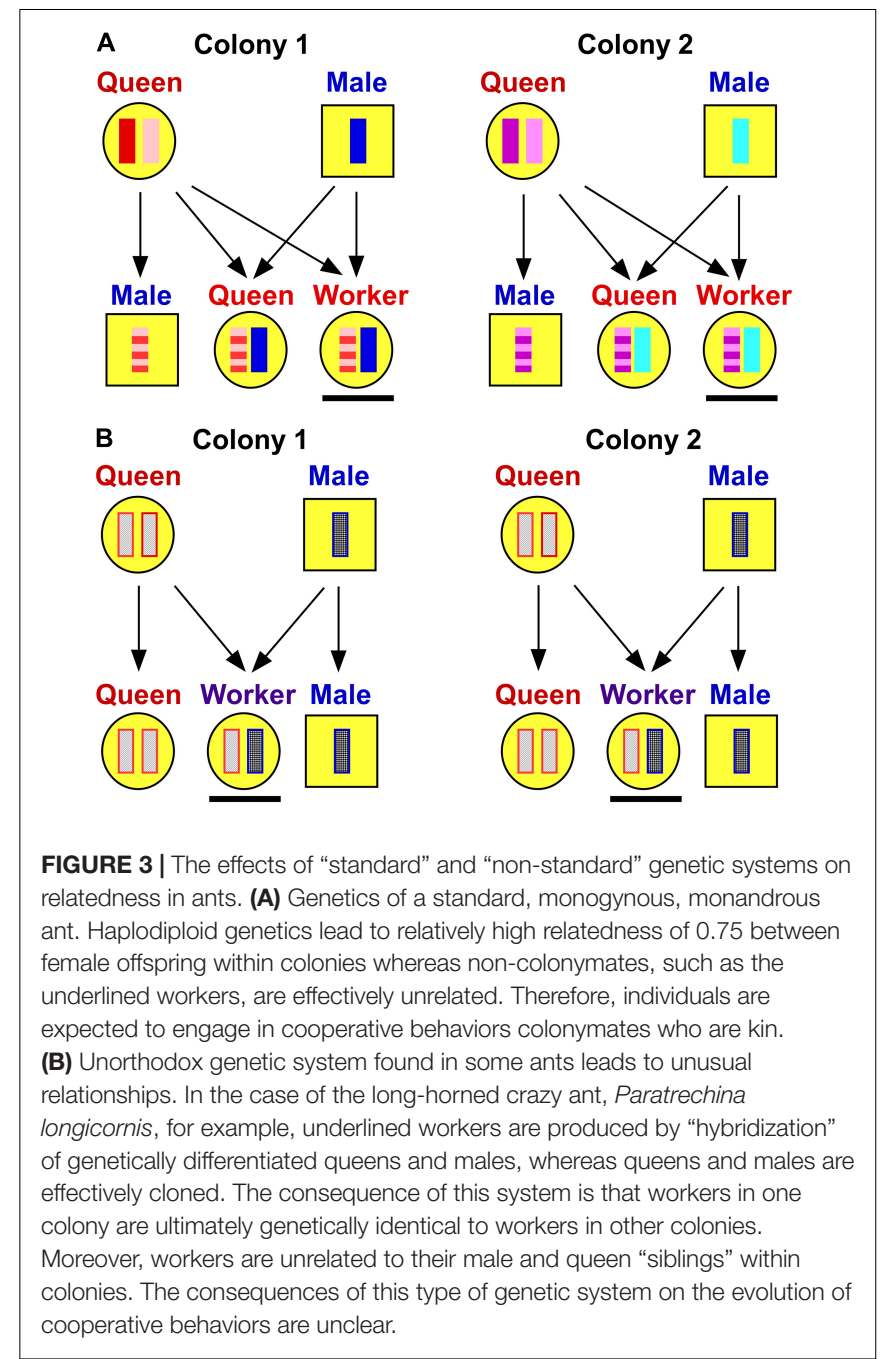

communal use of trail pheromones. For example, "ant gardens" in the Neotropics (Davidson, 1988; Orivel et al., 1997) and in Asian rainforests (Kaufmann and Maschwitz, 2006; Menzel and Bluthgen, 2010) are often co-inhabited by species from the genera Crematogaster and Camponotus (along with a number of other genera). These associations start when ants collect seeds of specialized epiphytes or other plants, and incorporate them into carton or soil where the plants grow to increase the size and stability of the ant nest. While brood chambers are kept separate, the rest of the colonies mix freely within the joint nest. In addition to sharing foraging trails to plant-based resources (Menzel et al., 2010), both species will defend the nest although larger Camponotus tend to exhibit the majority of the defensive behaviors (Menzel and Bluthgen, 2010).

Fungus growing ants also exhibit a variety of parabiotic associations (Sanhudo et al., 2008; Adams et al., 2013). For example, Megalomyrmex "guest ants" were originally thought to be social parasites of fungus growing ants due to their negative effect on host colony growth and garden biomass (Adams et al., 2012). However, Megalomyrmex ants apparently provide some benefits because they prevent raids by the 
genus Gnamptogenys, which are specialized agro-predators and are a high source of mortality to Trachymyrmex and Sericomyrmex fungus growing ants (Dijkstra and Boomsma, 2003). Megalomyrmex patrol the nests of their host and prevent raids by producing an alkaloid venom that is both highly toxic to the raiders as well as disrupts their nestmate recognition system (Adams et al., 2013).

Parabiotic associations are interesting as they highlight beneficial consequences of having an environmental or learned, as opposed to strictly "genetic," nest-mate recognition system (Menzel et al., 2008; Emery, 2013; Neupert et al., 2018). They are also fascinating models to study the context dependent nature of species interactions (e.g., parasitism vs. cooperation) (Adams et al., 2013; Menzel et al., 2014). As with queen associations, parabiotic and plesiobiotic associations may be driven by nest site limitation (Kanizsai et al., 2013), although more work is needed to understand how and why these associations evolve.

\section{FUTURE DIRECTIONS}

A great deal of important research has been conducted in the study of non-kin cooperation in ants. For example, the use of genetic markers has given us insight into the general frequency and distribution of non-kin cooperative activities. Experimental work has yielded important information on the behaviors that govern non-kin cooperation in some settings. Theoretical discussions have also provided insight into the processes that govern the evolution of cooperative interactions. However, despite these advances, there is still a great deal that remains to be understood about non-kin cooperation in ants. Below, we outline eight areas that should be a priority for future study.

1. Proximate mechanisms: Additional research is needed on understanding the proximate mechanisms involved in non-kin cooperation. What sensory modalities operate in non-kin interactions? How do these modalities function? What cognitive processes occur during kin vs. non-kin cooperation and discrimination? How are these processes shaped by developmental factors including experience?

2. Invasive ants: Native and introduced populations of ants often display major differences in social structure, with many invasive ants showing non-kin cooperation. However, more research is needed on understanding patterns of cooperation in native vs. invasive ants. Indeed, for many species, we have yet to identify the native source of introduced populations to make such comparisons. We still need fundamental information such as the relatedness of queens and workers in native populations. We also need to learn if changes in social structure are the consequence of increased costs associated with colony founding or whether they result from genetic changes associated with the invasion process.

3. Cheating: Evolutionary theory suggests that many types of non-kin cooperation should be susceptible to cheating.
For example, selection should favor the ability of workers to discriminate between related vs. unrelated queens. So, can we determine if cheating occurs? Does nonkin cooperation involve enforcement mechanisms or conflict? Can we identify and experimentally manipulate recognition cues such as cuticular hydrocarbons to "cause" nepotistic interactions? We also need to learn what genetic systems underlie recognition processes. And, if environmental nest mate recognition is susceptible to cheating, why have genetic-based nest-mate recognition systems not evolved?

3. Social parasitism: The presence of unrelated queens within ant nests sets up potentially interesting dynamics. For example, unrelated new queens could be viewed as social parasites within the colony. Thus, the evolutionary persistence of such colonies represents somewhat of a puzzle. Can polygyny select for variation in queen morphology (e.g., ergatoids queens)? Is queen polymorphism a first step toward parasitism? Can genetic changes be identified that are associated with parasitic behaviors?

4. Variation in queen number: Many ants, such as some species in the genera Formica, Leptothorax, Linepithema, Myrmica, and Solenopsis, are polygyne for part of their life cycle, or show variation in queen number among colonies or seasonally within colonies. What determines how many queens a colony has? What are the proximate mechanisms involved in determining queen number? And does colony queen number actually match evolutionary expectations?

5. Parabiosis: Interspecific cooperative actions between ant species is of considerable interest. Indeed, parabiosis may be common, but is understudied. We need more research aimed at understanding how often interspecific ant cooperation occurs. What types of cooperative interactions occur between species? What are the fitness consequences? How often do the interactions change from cooperative to parasitic?

6. Genetics: Mapping phenotype to genotype has been a core goal for many evolutionary biologists. But understanding how genetic variation leads to behavioral variation is difficult. Future studies should seek to understand how genetic variation is linked to variation in cooperative actions. For example, recently, "supergenes"-large nonrecombining regions of the genome- have been found to be involved in social evolution in a variety of taxa. Do such supergenes underlie certain types of polygyny and lead to non-kin cooperation? If so, what genes are involved in these behaviors and how do they evolve?

7. Environment: Theory has provided abundant explanations for how environmental variation should affect non-kin cooperation. However, we have a poor understanding of how and when the environment selects for pleometrotic associations. Thus, more experimental research is needed to understand exactly what environmental conditions lead to cooperative actions.

8. Distribution/Phylogeny: Non-kin cooperation is patchily 
distributed. So why does non-kin cooperation occur in some species but not others? What evolutionary pressures differ in these cases? And what proximate mechanisms allow non-kin cooperation to occur in only some taxa?

\section{AUTHOR CONTRIBUTIONS}

Both authors listed have made a substantial, direct and intellectual contribution to the work, and approved it for publication.

\section{REFERENCES}

Adams, R. M. M., Liberti, J., Illum, A. A., Jones, T. H., Nash, D. R., and Boomsma, J. J. (2013). Chemically armed mercenary ants protect fungus-farming societies. Proc. Natl. Acad. Sci. U.S.A. 110, 15752-15757. doi: 10.1073/pnas.1311654110

Adams, R. M. M., Shah, K., Antonov, L. D., and Mueller, U. G. (2012). Fitness consequences of nest infiltration by the mutualist-exploiter Megalomyrmex adamsae. Ecol. Entomol. 37, 453-462. doi: 10.1111/j.1365-2311.2012.01384.x

Aron, S., and Deneubourg, J. L. (2020). Colony co-founding in ants is an active process by queens. Sci. Rep. 10:13539. doi: 10.1038/s41598-020-70497-x

Arsenault, S. V., King, J. T., Kay, S., Lacy, K. D., Ross, K. G., and Hunt, B. G. (2020). Simple inheritance, complex regulation: supergene-mediated fire ant queen polymorphism. Mol. Ecol. 29, 3622-3636. doi: 10.1111/mec.15581

Barker, J. L., Bronstein, J. L., Friesen, M. L., Jones, E. I., Reeve, H. K., Zink, A. G., et al. (2017). Synthesizing perspectives on the evolution of cooperation within and between species. Evolution 71, 814-825. doi: 10.1111/evo.13174

Bernasconi, G., and Keller, L. (1996). Reproductive conflicts in cooperative associations of fire ant queens (Solenopsis invicta). Proc. Roy. Soc B Biol. Sci. 263, 509-513. doi: 10.1098/rspb.1996.0077

Bernasconi, G., and Strassmann, J. E. (1999). Cooperation among unrelated individuals: the ant foundress case. Trends Ecol. Evol. 14, 477-482. doi: 10.1016/ S0169-5347(99)01722-X

Bernasconi, G., Krieger, M. J. B., and Keller, L. (1997). Unequal partitioning of reproduction and investment between cooperating queens in the fire ant, Solenopsis invicta, as revealed by microsatellites. Proc. Roy. Soc B Biol. Sci. 264, 1331-1336. doi: 10.1098/rspb.1997.0184

Bertelsmeier, C., Ollier, S., Liebhold, A., and Keller, L. (2017). Recent human history governs global ant invasion dynamics. Nat. Ecol. Evol. 1, 0184. doi: 10.1038/ s41559-017-0184

Boomsma, J. J., and d'Ettorre, P. (2013). Nice to kin and nasty to non-kin: revisiting Hamilton's early insights on eusociality. Biol. Lett. 9:4. doi: 10.1098/rsbl.2013. 0444

Boomsma, J. J., Huszar, D. B., and Pedersen, J. S. (2014). The evolution of multiqueen breeding in eusocial lineages with permanent physically differentiated castes. Anim. Behav. 92, 241-252. doi: 10.1016/j.anbehav.2014. 03.005

Boulay, R., Arnan, X., Cerda, X., and Retana, J. (2014). The ecological benefits of larger colony size may promote polygyny in ants. J. Evol. Biol. 27, 2856-2863. doi: $10.1111 /$ jeb.12515

Brodetzki, T. R., Brodetzki, G., Feinerman, O., and Hefetz, A. (2020). Worker demography and behavior in a supercolonial ant colony: the case of the desert ant Cataglyphis niger. Ethology 126, 59-67. doi: 10.1111/eth.12960

Clark, R. M., and Fewell, J. H. (2014). Social dynamics drive selection in cooperative associations of ant queens. Behav. Ecol. 25, 117-123. doi: 10.1093/beheco/ art093

Cronin, A. L., Molet, M., Doums, C., Monnin, T., and Peeters, C. (2013). Recurrent evolution of dependent colony foundation across eusocial insects. Annu. Rev. Entomol. 58, 37-55. doi: 10.1146/annurev-ento-120811-153643

Crozier, R. H., Newey, P. S., Schluns, E. A., and Robson, S. K. A. (2010). A masterpiece of evolution - Oecophylla weaver ants (Hymenoptera: Formicidae). Myrmecol. News 13, 57-71.

Davidson, D. W. (1988). Ecological-studies of neotropical ant gardens. Ecology 69, 1138-1152. doi: $10.2307 / 1941268$

\section{FUNDING}

This work was partially supported by the National Science Foundation (NSF-IOS-2019799 and NSF DEB-2105033 to MG and NSF IOS-1755336 to AS).

\section{ACKNOWLEDGMENTS}

We thank members of the Suarez lab for comments on an earlier version of this manuscript.

Dijkstra, M. B., and Boomsma, J. J. (2003). Gnamptogenys hartmani wheeler (Ponerinae : Ectatommini): an agro-predator of Trachymyrmex and Sericomyrmex fungus-growing ants. Naturwissenschaften 90, 568-571. doi: 10.1007/s00114-003-0478-4

Eliyahu, D., Ross, K. G., Haight, K. L., Keller, L., and Liebig, J. (2011). Venom alkaloid and cuticular hydrocarbon profiles are associated with social organization, queen fertility status, and queen genotype in the fire ant Solenopsis invicta. J. Chem. Ecol. 37, 1242-1254. doi: 10.1007/s10886-011-0037-y

Ellis, S., and Robinson, E. J. H. (2014). Polydomy in red wood ants. Insectes Soc. 61, 111-122. doi: 10.1007/s00040-013-0337-z

Emery, V. J. (2013). The Chemistry, Recognition Behaviors, And Population Genetics Of Neotropical Parabiotic Ants. Ph.D. thesis. Berkeley, CA: University of California.

Eriksson, T. H., Holldobler, B., Taylor, J. E., and Gadau, J. (2019). Intraspecific variation in colony founding behavior and social organization in the honey ant Myrmecocystus mendax. Insectes Soc. 66, 283-297. doi: 10.1007/s00040-01900687-y

Errard, C., Regla, J. I., and Hefetz, A. (2003). Interspecific recognition in Chilean parabiotic ant species. Insectes Soc. 50, 268-273. doi: 10.1007/s00040-0030677-1

Eyer, M., and Vargo, E. L. (2021). Breeding structure and invasiveness in social insects. Curr. Opin. Insect Sci. 46, 24-30. doi: 10.1016/j.cois.2021.01.004

Eyer, P. A., Blumenfeld, A. J., and Vargo, E. L. (2019). Sexually antagonistic selection promotes genetic divergence between males and females in an ant. Proc. Natl. Acad. Sci. U.S.A. 116, 24157-24163. doi: 10.1073/pnas.1906568116

Eyer, P. A., Leniaud, L., Darras, H., and Aron, S. (2013). Hybridogenesis through thelytokous parthenogenesis in two Cataglyphis desert ants. Mol. Ecol. 22, 947-955. doi: 10.1111/mec.12141

Fletcher, D. J. C., and Blum, M. (1983). Regulation of queen number by workers in colonies of social insects. Science 219, 312-314. doi: 10.1126/science.219.45 82.312

Foucaud, J., Estoup, A., Loiseau, A., Rey, O., and Orivel, J. (2010). Thelytokous parthenogenesis, male clonality and genetic caste determination in the little fire ant: new evidence and insights from the lab. Heredity 105, 205-212. doi: 10.1038/hdy.2009.169

Foucaud, J., Fournier, D., Orivel, J., Delabie, J. H. C., Loiseau, A., Le Breton, J., et al. (2007). Sex and clonality in the little fire ant. Mol. Biol. Evol. 24, 2465-2473. doi: $10.1093 / \mathrm{molbev} / \mathrm{msm} 180$

Foucaud, J., Orivel, J., Fournier, D., Delabie, J. H. C., Loiseau, A., Le Breton, J., et al. (2009). Reproductive system, social organization, human disturbance and ecological dominance in native populations of the little fire ant, Wasmannia auropunctata. Mol. Ecol. 18, 5059-5073. doi: 10.1111/j.1365-294X.2009.0 4440.x

Fournier, D., Battaille, G., Timmermans, I., and Aron, S. (2008). Genetic diversity, worker size polymorphism and division of labour in the polyandrous ant Cataglyphis cursor. Anim. Behav. 75, 151-158. doi: 10.1016/j.anbehav.2007. 04.023

Fournier, D., Estoup, A., Foucaud, J., Orivel, J., Foucaud, J., Jourdan, H., et al. (2005). Clonal reproduction by males and females in the little fire ant Wasmannia auropunctata. Nature 435, 1230-1234. doi: 10.1038/nature03705

Giraud, T., Pedersen, J. S., and Keller, L. (2002). Evolution of supercolonies: the Argentine ants of southern Europe. Proc. Natl. Acad. Sci. U.S.A. 99, 6075-6079. doi: 10.1073/pnas.092694199 
Goodisman, M. A. D., and Ross, K. G. (1998). A test of queen recruitment models using nuclear and mitochondrial markers in the fire ant Solenopsis invicta. Evolution 52, 1416-1422. doi: 10.1111/j.1558-5646.1998.tb02023.x

Gotzek, D. (2007). Genetic regulation of colony social organization in fire ants: an integrative overview. Q. Rev. Biol. 82, 201-226. doi: 10.1086/519965

Goudie, F., and Oldroyd, B. P. (2018). The distribution of thelytoky, arrhenotoky and androgenesis among castes in the eusocial Hymenoptera. Insectes Soc. 65, 5-16. doi: 10.1007/s00040-017-0597-0

Hakala, S. M., Ittonen, M., Seppa, P., and Helanter, H. (2020). Limited dispersal and an unexpected aggression pattern in a native supercolonial ant. Ecol. Evol. 10, 3671-3685. doi: 10.1002/ece3.6154

Hamilton, W. D. (1964). The genetical evolution of social behaviour. J. Theor. Biol. 7, 1-52. doi: 10.1016/0022-5193(64)90038-4

Haney, B. R., and Fewell, J. H. (2018). Ecological drivers and reproductive consequences of non-kin cooperation by ant queens. Oecologia 187, 643-655. doi: 10.1007/s00442-018-4148-9

Heinze, J., and Tsuji, K. (1995). Ant reproductive strategies. Res. Popul. Ecol. 37, 135-149. doi: 10.1007/BF02515814

Helantera, H., Strassmann, J. E., Carrillo, J., and Queller, D. C. (2009). Unicolonial ants: where do they come from, what are they and where are they going? Trends Ecol. Evol. 24, 341-349. doi: 10.1016/j.tree.2009.01.013

Helmkampf, M., Mikheyev, A. S., Kang, Y., Fewell, J., and Gadau, J. (2016). Gene expression and variation in social aggression by queens of the harvester ant Pogonomyrmex californicus. Mol. Ecol. 25, 3716-3730. doi: 10.1111/mec. 13700

Helms Cahan, S., and Fewell, J. H. (2004). Division of labor and the evolution of task sharing in queen associations of the harvester ant Pogonomyrmex californicus. Behav. Ecol. Sociobiol. 56, 9-17. doi: 10.1007/s00265-0030746-5

Hölldobler, B., and Wilson, E. O. (1977). The number of queens: an important trait in ant evolution. Naturwissenschaften 64, 8-15. doi: 10.1007/BF00439886

Hölldobler, B., and Wilson, E. O. (1990). The Ants. Cambridge, MA: The Belknap Press of Harvard University Press. doi: 10.1007/978-3-662-10306-7

Holway, D. A., Lach, L., Suarez, A. V., Tsutsui, N. D., and Case, T. J. (2002). The causes and consequences of ant invasions. Annu. Rev. Ecol. Syst. 33, 181-233. doi: 10.1146/annurev.ecolsys.33.010802.150444

Hughes, W. O. H., Oldroyd, B. P., Beekman, M., and Ratnieks, F. L. W. (2008). Ancestral monogamy shows kin selection is key to the evolution of eusociality. Science 320, 1213-1216. doi: 10.1126/science.1156108

Jackson, D. E. (2007). Social evolution: Pathways to ant unicoloniality. Curr. Biol. 17, R1063-R1064. doi: 10.1016/j.cub.2007.10.031

Kanizsai, O., Lorinczi, G., and Galle, L. (2013). Nesting associations without interdependence: a preliminary review on plesiobiosis in ants. Psyche 2013:238602. doi: 10.1155/2013/238602

Kaufmann, E., and Maschwitz, U. (2006). Ant-gardens of tropical Asian rainforests. Naturwissenschaften 93, 216-227. doi: 10.1007/s00114-005-0081-y

Kay, T., Keller, L., and Lehmann, L. (2020). The evolution of altruism and the serial rediscovery of the role of relatedness. Proc. Natl. Acad. Sci. U.S.A. 117, 28894-28898. doi: 10.1073/pnas.2013596117

Keller, L. (1991). Queen number, mode of colony founding, and queen reproductive success in ants (Hymenoptera Formicidae). Ethol. Ecol. Evol. 3, 307-316. doi: 10.1080/08927014.1991.9525359

Keller, L. (1993). Queen Number And Sociality In Insects. Oxford: Oxford University Press.

Keller, L., and Ross, K. G. (1998). Selfish genes: a green beard in the red fire ant. Nature 394, 573-575. doi: 10.1038/29064

Krieger, M. J. B., and Ross, K. G. (2005). Molecular evolutionary analyses of the odorant-binding protein gene Gp-9 in fire ants and other Solenopsis species. Mol. Biol. Evol. 22, 2090-2103. doi: 10.1093/molbev/msi203

Kronauer, D. J. C., Pierce, N. E., and Keller, L. (2012). Asexual reproduction in introduced and native populations of the ant Cerapachys biroi. Mol. Ecol. 21, 5221-5235. doi: 10.1111/Mec.12041

Kummerli, R., and Keller, L. (2007). Contrasting population genetic structure for workers and queens in the putatively unicolonial ant Formica exsecta. Mol. Ecol. 16, 4493-4503. doi: 10.1111/j.1365-294X.2007.03514.x

Lacy, K. D., Shoemaker, D., and Ross, K. G. (2019). Joint evolution of asexuality and queen number in an ant. Curr. Biol. 29, 1394-1400. doi: 10.1016/j.cub.2019. 03.018
Lehmann, L., and Rousset, F. (2010). How life history and demography promote or inhibit the evolution of helping behaviours. Philos. Trans. R. Soc. Lond. B Biol. Sci. 365, 2599-2617. doi: 10.1098/rstb.2010.0138

Leniaud, L., Pichon, A., Uva, P., and Bagneres, A. G. (2009). Unicoloniality in Reticulitermes urbis: a novel feature in a potentially invasive termite species. Bull. Entomol. Res. 99, 1-10. doi: 10.1017/S0007485308006032

Masoni, A., Frizzi, F., Turillazzi, S., and Santini, G. (2019). Making the right choice: how Crematogaster scutellaris queens choose to co-found in relation to nest availability. Insectes Soc. 66, 257-263. doi: 10.1007/s00040-018-00683-8

Maynard Smith, J., and Szathmary, E. (1998). The Major Transitions In Evolution. Oxford: Oxford University Press. doi: 10.1093/oso/9780198502944.001.0001

Menzel, F., and Bluthgen, N. (2010). Parabiotic associations between tropical ants: equal partnership or parasitic exploitation? J. Anim. Ecol. 79, 71-81. doi: 10. $1111 /$ j.1365-2656.2009.01628.x

Menzel, F., Kriesell, H., and Witte, V. (2014). Parabiotic ants: the costs and benefits of symbiosis. Ecol. Entomol. 39, 436-444. doi: 10.1111/een.12116

Menzel, F., Linsenmair, K. E., and Bluthgen, N. (2008). Selective interspecific tolerance in tropical Crematogaster-Camponotus associations. Anim. Behav. 75, 837-846. doi: 10.1016/j.anbehav.2007.07.005

Menzel, F., Pokorny, T., Bluthgen, N., and Schmitt, T. (2010). Trail-sharing among tropical ants: interspecific use of trail pheromones? Ecol. Entomol. 35, 495-503. doi: 10.1111/j.1365-2311.2010.01206.x

Moffett, M. W. (2012). Supercolonies of billions in an invasive ant: what is a society? Behav. Ecol. 23, 925-933. doi: 10.1093/beheco/ars043

Neupert, S., Demilto, A., Drijfhout, F., Speller, S., and Adams, R. M. M. (2018). Host colony integration: megalomyrmex guest ant parasites maintain peace with their host using weaponry. Anim. Behav. 139, 71-79. doi: 10.1016/j.anbehav. 2018.02.021

Ohkawara, K., Nakayama, M., Satoh, A., Trindl, A., and Heinze, J. (2006). Clonal reproduction and genetic caste differences in a queen-polymorphic ant, Vollenhovia emeryi. Biol. Lett. 2, 359-363. doi: 10.1098/rsbl.2006.0491

Okamoto, M., Kobayashi, K., Hasegawa, E., and Ohkawara, K. (2015). Sexual and asexual reproduction of queens in a myrmicine ant, Vollenhovia emeryi (Hymenoptera: Formicidae). Myrmecol. News 21, 13-17.

Orivel, J., Errard, C., and Dejean, A. (1997). Ant gardens: interspecific recognition in parabiotic ant species. Behav. Ecol. Sociobiol. 40, 87-93. doi: 10.1007/ s002650050319

Ostwald, M. M., Guo, X., Wong, T., Malaekeh, A., Harrison, J. F., and Fewell, J. H. (2021). Cooperation among unrelated ant queens provides persistent growth and survival benefits during colony ontogeny. Sci. Rep. 11:8332. doi: 10.1038/ s41598-021-87797-5

Overson, R., Fewell, J., and Gadau, J. (2016). Distribution and origin of intraspecific social variation in the California harvester ant Pogonomyrmex californicus. Insectes Soc. 63, 531-541. doi: 10.1007/s00040-016-0497-8

Pearcy, M., Goodisman, M. A. D., and Keller, L. (2011). Sib mating without inbreeding in the longhorn crazy ant. Proc. Roy. Soc B Biol. Sci. 278, 2677-2681. doi: $10.1098 /$ rspb.2010.2562

Peeters, C., and Andersen, A. N. (1989). Cooperation between dealate queens during colony foundation in the green tree ant, Oecophylla smaragdina. Psyche 96, 39-44. doi: 10.1155/1989/12368

Peeters, C., and Ito, F. (2001). Colony dispersal and the evolution of queen morphology in social Hymenoptera. Annu. Rev. Entomol. 46, 601-630. doi: 10.1146/annurev.ento.46.1.601

Purcell, J., Pellissier, L., and Chapuisat, M. (2015). Social structure varies with elevation in an Alpine ant. Mol. Ecol. 24, 498-507. doi: 10.1111/mec.13042

Rabeling, C., and Kronauer, D. J. C. (2013). Thelytokous parthenogenesis in eusocial hymenoptera. Annu. Rev. Entomol. 58, 273-298. doi: 10.1146/annurevento-120811-153710

Ross, K. G., and Matthews, R.W. (eds.) (1991). The Social Biology Of Wasps. Ithaca, NY: Comstock Publishing Associates. doi: 10.7591/9781501718670

Sanhudo, C. E. D., Izzo, T. J., and Brandao, C. R. F. (2008). Parabiosis between basal fungus-growing ants (Formicidae, Attini). Insectes Soc. 55, 296-300. doi: 10.1007/s00040-008-1005-6

Schluns, H., and Crozier, R. H. (2009). Molecular and chemical immune defenses in ants (Hymenoptera: Formicidae). Myrmecol. News 12, 237-249.

Schwander, T., and Oldroyd, B. P. (2016). Androgenesis: where males hijack eggs to clone themselves. Philos. Trans. R. Soc. B Biol. Sci. 371:13. doi: 10.1098/rstb. 2015.0534 
Schwander, T., Rosset, H., and Chapuisat, M. (2005). Division of labour and worker size polymorphism in ant colonies: the impact of social and genetic factors. Behav. Ecol. Sociobiol. 59, 215-221. doi: 10.1007/s00265-005-0027-6

Seppa, P., Johansson, H., Gyllenstrand, N., Palsson, S., and Pamilo, P. (2012). Mosaic structure of native ant supercolonies. Mol. Ecol. 21, 5880-5891. doi: $10.1111 /$ mec. 12070

Shaffer, Z., Sasaki, T., Haney, B., Janssen, M., Pratt, S. C., and Fewell, J. H. (2016). The foundress's dilemma: group selection for cooperation among queens of the harvester ant Pogonomyrmex californicus. Sci. Rep. 6:29828. doi: 10.1038/ srep 29828

Smith, C. R., Toth, A. L., Suarez, A. V., and Robinson, G. E. (2008). Genetic and genomic analyses of the division of labour in insect societies. Nat. Rev. Genet. 9, 735-748. doi: 10.1038/nrg2429

Sorger, D. M., Booth, W., Eshete, A. W., Lowman, M., and Moffett, M. W. (2017). Outnumbered: a new dominant ant species with genetically diverse supercolonies in Ethiopia. Insectes Soc. 64, 141-147. doi: 10.1007/s00040-0160524-9

Sundström, L., Seppa, P., and Pamilo, P. (2005). Genetic population structure and dispersal patterns in Formica ants - a review. Ann. Zool. Fenn. 42, 163-177.

Teggers, E. M., Deegener, F., and Libbrecht, R. (2021). Fecundity determines the outcome of founding queen associations in ants. Sci. Rep. 11:2986. doi: 10.1038/ s41598-021-82559-9

Trible, W., and Ross, K. G. (2016). Chemical communication of queen supergene status in an ant. J. Evol. Biol. 29, 502-513. doi: 10.1111/jeb.12799

Tschinkel, W. R., and Howard, D. F. (1983). Colony founding by pleometrosis in the fire ant, Solenopsis invicta. Behav. Ecol. Sociobiol. 12, 103-113. doi: 10.1007/BF00343200

Tsutsui, N. D., and Suarez, A. V. (2003). The colony structure and population biology of invasive ants. Conserv. Biol. 17, 48-58. doi: 10.1046/j.1523-1739. 2003.02018.x

Urbani, C. B. (1991). Indiscriminate oophagy by ant larvae - an explanation for brood serial organization. Insectes Soc. 38, 229-239. doi: 10.1007/Bf01314909
West, S. A., Cooper, G. A., Ghoul, M. B., and Griffin, A. S. (2021). Ten recent insights for our understanding of cooperation. Nat. Ecol. Evol 5, 419-430. doi: 10.1038/s41559-020-01384- $\mathrm{x}$

West, S. A., El Mouden, C., and Gardner, A. (2011). Sixteen common misconceptions about the evolution of cooperation in humans. Evol. Hum. Behav. 32, 231-262. doi: 10.1016/j.evolhumbehav.2010.08.001

West, S. A., Griffin, A. S., and Gardner, A. (2007b). Social semantics: altruism, cooperation, mutualism, strong reciprocity and group selection. J. Evol. Biol. 20, 415-432.

West, S. A., Griffin, A. S., and Gardner, A. (2007a). Evolutionary explanations for cooperation. Curr. Biol. 17, R661-R672.

Wilson, E. O. (1965). Trail sharing in ants. Psyche 72, 1-7.

Yan, Z., Martin, S. H., Gotzek, D., Arsenault, S. V., Duchen, P., Helleu, Q., et al. (2020). Evolution of a supergene that regulates a trans-species social polymorphism. Nat. Ecol. Evol. 4, 240-249. doi: 10.1038/s41559-0191081-1

Conflict of Interest: The authors declare that the research was conducted in the absence of any commercial or financial relationships that could be construed as a potential conflict of interest.

Publisher's Note: All claims expressed in this article are solely those of the authors and do not necessarily represent those of their affiliated organizations, or those of the publisher, the editors and the reviewers. Any product that may be evaluated in this article, or claim that may be made by its manufacturer, is not guaranteed or endorsed by the publisher.

Copyright (C) 2021 Suarez and Goodisman. This is an open-access article distributed under the terms of the Creative Commons Attribution License (CC BY). The use, distribution or reproduction in other forums is permitted, provided the original author(s) and the copyright owner(s) are credited and that the original publication in this journal is cited, in accordance with accepted academic practice. No use, distribution or reproduction is permitted which does not comply with these terms. 